\title{
K-MEANS CLUSTER ANALYSIS OF SUB-DISTRICTS IN SIDOARJO BASED ON LONG-TERM CONTRACEPTIVE METHOD
}

\author{
Cempaka Puspita Siwi ${ }^{1}$, Yasmine Nurfirdaus ${ }^{2}$ \\ ${ }^{1}$ Department of Occupational Safety and Health, Faculty of Public Health, Universitas Airlangga, 60115 Surabaya, \\ East Java, Indonesia \\ ${ }^{2}$ Department of Biostatistics and Population, Faculty of Public Health, Universitas Airlangga, 60115 Surabaya, \\ East Java, Indonesia \\ Corresponding Author: Cempaka Puspita Siwi \\ E-mail: cempaka.puspita.siwi-2016@ fkm.unair.ac.id
}

\begin{abstract}
The success of the Family Planning program can be measured from the ratio of the use of the Long-Term Contraceptive Method by the couples of childbearing age in each region. The approach used in the Family Planning program is a regional approach, so this study aimed to group sub-districts based on the proportion users of the Long-Term Contraceptive Method by couples of childbearing age in Sidoarjo in 2018. This study was non-reactive study, which is a type of research using secondary data. The data source came from the Report of the Office of Women's Empowerment and Child Protection, Family Planning Sidoarjo in 2018. This study used cross-sectional design with the K-Means Clustering model data analysis. The results of this study produced three regional clusters: Cluster 1 with a low success rate sub-districts category with 8 sub-districts; Cluster 2 with a medium success rate category that has 6 subdistrict members; and Cluster 3 with a high success rate category consisting of 4 subdistricts in Sidoarjo. Based on the study results, broad accessibility was needed to obtain information so that the level of the Long-Term Contraceptive Method users in Sidoarjo increases.
\end{abstract}

Keywords: k-means cluster, proportion, long-term contraceptive method

\section{ABSTRAK}

Keberhasilan program Keluarga Berencana terlihat dari rasio penggunaan Metode Kontrasepsi Jangka Panjang (MKJP) oleh Pasangan Usia Subur (PUS) di setiap wilayah. Pendekatan yang digunakan program Keluarga Berencana merupakan pendekatan wilayah, maka penelitian ini bertujuaan mengelompokkan wilayah kecamatan berdasarkan proporsi pengguna Metode Kontrasepsi Jangka Panjang (MKJP) oleh Pasangan Usia Subur (PUS) di Kabupaten Sidoarjo pada tahun 2018. Penelitian menggunakan metode non-reactive study yang merupakan jenis penelitian menggunakan data sekunder. Sumber data berasal dari Laporan Dinas Pemberdayaan Perempuan dan Perlindungan Anak, Keluarga Berencana (DP3AKB) Kabupaten Sidoarjo tahun 2018. Rancang bangun penelitian ini adalah cross sectional dengan menggunakan analisis data model K-Means Clustering. Hasil penelitian ini menghasilkan tiga cluster wilayah: (1) cluster 1 dengan kategori kecamatan tingkat keberhasilan rendah yang beranggota 8 kecamatan; (2) cluster 2 dengan kategori kecamatan tingkat keberhasilan sedang yang memiliki anggota 6 kecamatan; dan (3) cluster 3 dengan kategori tingkat keberhasilan tinggi yang beranggotakan 4 kecamatan yang ada di Sidoarjo. Berdasarkan hasil penelitian, diperlukan aksesibilitas yang luas unuk memperoleh informasi agar tingkat pengguna MKJP di Kabupaten Sidoarjo meningkat.

Kata kunci: cluster k-means, proporsi, metode kontrasepsi jangka panjang

\section{INTRODUCTION}

Every year, the population in Indonesia increases proved by the results of the population census carried out in 2000 when the number had reached $206,264,595$ people. In the next census carried out in 2010, the number increased to 237,641,326 people (Central Bureau of Statistics, 2012). The population growth rate from the census from 2010 to 2016 was estimated at $1.36 \%$ per year (Central Bureau of Statistics, 2017). This data shows a continuous increase in population in Indonesia. A large number of population in Indonesia indeed produces various positive and negative impacts on the community. One negative impact that is influential and significant arises of the large 
population is poverty by 0.96 or $96 \%$ (Azizah, Sudarti, and Kusuma, 2018). The long-term impact of a large population has a positive effect because many residents are entering productive age; when it is balanced with good quality, human resources can also have a good effect on per capita income (Peterson, 2017).

Increased population growth urges the government to design programs to reduce the high growth rate through the Family Planning Program. The program has an underlying, planned, and comprehensive meaning aiming to provide welfare and essential health for the whole community (Öztürk İnal et al., 2017). The family planning program includes health promotion and protection that seeks to plan and regulate the distance and age for childbirth and pregnancy to be compatible with reproductive rights in achieving a prosperous and healthy family (Indonesian Ministry of Health, 2013).

The family planning program has a strategic plan to balance the amount of contraceptive needed based on couples of childbearing age requests (Wati, Puspitasari, and Purwaningsih, 2019). The use of contraceptives based on the methods are divided into two: long-term contraceptive method such as tubectomy (4\%), vasectomy $(0.1 \%)$, implants (5\%), and IUD (5); and nonlong-term contraceptive method such as suntik $\mathrm{KB} /$ injections (29\%), and pills (12\%). From both methods, the primary target is long-term contraceptive method (National Board of Population and Family Planning et al., 2018). The long-term contraceptive method and nonlong-term contraceptive method targets from 2015-2019 are increasing each year from $65.2 \%$ to $66 \%$ with the main target in the the long-term contraceptive method is $23.5 \%$ of the number of active couples of childbearing age, based on the SKAP 2019 results of family planning use with the non-long-term contraceptive method (75.4\%) is more widely used than the long-term contraceptive method in each year, but for the main target of the longterm contraceptive method has been fulfilled in 2019 which is $24.6 \%$ (National Board of Population and Family Planning and Central Bureau of Statistics, 2019).

The use of contraceptive in rural areas $(66 \%)$ is higher than in urban areas (64\%) since couples of childbearing age's knowledge in rural areas is increasing. However, based on the method it has differences in the long-term contraceptive method that are more numerous in urban areas and more non-long-term contraceptive method in rural areas such as the IUD method is $2.8 \%$ and urban areas is $4.8 \%$, and the implant method in rural areas is $6.6 \%$, and urban areas is $2.8 \%$ (National Board of Population and Family Planning et al., 2018). Things that significantly affect the selection of contraceptive methods are the age of women of childbearing age at 30-34 years old $(\mathrm{OR}=$ 1.16), wealth quintile index four or upper secondary $(\mathrm{OR}=1.25)$, occupation $(\mathrm{OR}=$ $0.95)$, secondary education level $(\mathrm{OR}=1.06)$, and urban areas $(\mathrm{OR}=0.82)$ (Idris, 2019).

The Family Planning program movement's principle is activities that must be carried out based on the needs of the community. The family planning program's implementation should be oriented towards the regional approach (Restiani, 2016). This regional approach can be applied by grouping an area according to specific characteristics, such as information on the prevalence of contraceptive users and knowledge using the cluster analysis method. Cluster analysis is a multivariate method for grouping an object or differentiating several objects based on almost the same or the same characteristics into a group with the same characteristics (Silvi, 2018).

Previous research has been conducted on the grouping of regions Nugroho and Wibowo (2019) to explain the grouping of regions, namely districts or cities with K-Means cluster based on the number of key populations in East Java. The application of this analysis can be used in grouping an area or region. One example is the grouping of provinces based on Contraceptive Prevalence Rate (CPR) as one of the variables (Yulianti, 2018). Other research on regional grouping, explains that grouping can be done based on the ratio of family planning acceptors or the proportion of contraceptive use methods (Restiani, 2016).

Regional groupings are not only used at the provincial level but can be done at the subdistrict level since family planning program is area-oriented. This grouping area can be done at the sub-provincial level or smaller at the subdistrict level. Previous research by grouping sub-districts based on the use of contraceptives was carried out in order to reduce the rate of population growth in the sub-district area, and from the results of the grouping will be used for planning for further family planning programs in the fulfillment, supply, and use of 
contraceptives (Khoirunnisa and Dzikkrullah, 2020).

This research can indicate that K-Means clustering can be used at a smaller area or subdistrict level, and can be based on the ratio of family planning users or the proportion of users of contraceptive methods, especially on longterm contraceptive method users, because these users can influence the growth rate.

The purpose of the research following the above problems is to group sub-districts based on the proportion of the long-term contraceptive method users in Sidoarjo in 2018.

\section{METHODS}

This type of research uses a non-reactive study. This study uses secondary data so that respondents in the study did not provide answers directly, but through other parties who have taken answers (Kuntoro, 2011). The study design was cross-sectional because the data collection was carried out within a period determined by the researcher. The study's time and location were conducted on December 23, 2019, to January 29, 2020, at the Women's Empowerment and Child Protection, Family Planning (DP3AKB) office in Sidoarjo. This research population comprises all couples of childbearing age with an age range of 15-49 years old in Sidoarjo.

The use of variables in the study is the proportion of the long-term contraceptive method users in the IUD (Intrauterine Device) method, vasectomy, tubectomy and implants or ratio of the long-term contraceptive method users towards couples of childbearing age for each sub-district in Sidoarjo. The data is sourced from the final report of the $2018 \mathrm{~KB}$ KK sub-section in DP3AKB Sidoarjo. Data analysis in this study used K-Means Clustering analysis which is included in the cluster analysis of non-hierarchical methods, K-means clustering or unsupervised learning is a data mining algorithm, to the group, or classify, objects based on attributes or features into a group or cluster (Parsian, 2015). Testing with K-Means Cluster analysis was performed using SPSS Statistics Version 21 application or software so that the results obtained by researchers will group an area based on districts through proportions users of the long-term contraceptive method in Sidoarjo. From the results of the grouping will be analyzed based on the characteristics of each group or cluster.

\section{RESULT}

The results obtained in the K-Means cluster analysis test based on the proportion of the long-term contraceptive method contraceptive use in Sidoarjo can be seen as follows.

\section{Distribution and Proportion of the Long- Term Contraception Method Users in Sidoarjo}

The distribution of the long-term contraceptive method users is the distribution of the number of couples of childbearing age who were the acceptors of long-term contraceptive method in Sidoarjo based on the sub-district area. The proportion of users were the results of the ratio calculation of the number of couples of childbearing age who chose to use the long-term contraceptive method and the total number of couples of childbearing age in the region, and the calculation can be written as follows:

$$
C P R=\frac{\sum \text { Akseptor } M K J P}{\sum P U S} \times 100 \%
$$

Table 1 shows that the number of active couples of childbearing age who use the longterm contraceptive method in the Sidoarjo is 83,971 couples with the proportion of contraceptive use of $21.75 \%$. The proportion of users using the long-term contraceptive method indicates that the IUD method has the most significant or most preferrable proportion of $11.01 \%$. The second sequence is tubectomy with the proportion of contraceptive users at $5.52 \%$. The next rank is the implant method, with a proportion of users of $5.07 \%$. Whereas the most unpreferrable contraceptive is vasectomy with a proportion of $0.15 \%$.

The most active couples of childbearing age who use the long-term contraceptive method belong to Waru sub-district area, as evidenced by the large proportion of contraceptive users by $33.88 \%$ with the number of active couples of childbearing age as many as 13,882 couples of childbearing age. It was contrary to the the long-term contraceptive method chosen by couple of childbearing age in Jabon, the proportion of contraceptive users is the lowest by $11.49 \%$. 
Table 1. Distribution and Proportion of the Long-Term Contraception Method Users in Each SubDistrict in Sidoarjo

\begin{tabular}{|c|c|c|c|c|c|c|}
\hline \multirow{2}{*}{ Sub-district } & \multirow{2}{*}{$\begin{array}{l}\text { Number } \\
\text { of WCA }\end{array}$} & \multicolumn{5}{|c|}{ WCA using the Long-Term Contraception Method } \\
\hline & & IUD & Tubectomy & Vasectomy & Implant & Total \\
\hline Tarik & 1,877 & $\begin{array}{c}545 \\
(3.42 \%)\end{array}$ & $\begin{array}{c}10 \\
(0.06 \%)\end{array}$ & $\begin{array}{c}745 \\
(4.68 \%)\end{array}$ & $\begin{array}{c}577 \\
(3.62 \%)\end{array}$ & $\begin{array}{c}1,877 \\
(11.78 \%)\end{array}$ \\
\hline Prambon & 2,821 & $\begin{array}{c}983 \\
(6.63 \%)\end{array}$ & $\begin{array}{c}20 \\
(0.13 \%)\end{array}$ & $\begin{array}{c}707 \\
(4.77 \%)\end{array}$ & $\begin{array}{c}1,111 \\
(7.49 \%)\end{array}$ & $\begin{array}{c}2,821 \\
(19.03 \%)\end{array}$ \\
\hline Krembung & 3,575 & $\begin{array}{c}1,514 \\
(9.32 \%)\end{array}$ & $\begin{array}{c}44 \\
(0.27 \%)\end{array}$ & $\begin{array}{c}936 \\
(5.76 \%)\end{array}$ & $\begin{array}{c}1,081 \\
(6.65 \%)\end{array}$ & $\begin{array}{c}3,575 \\
(22.00 \%)\end{array}$ \\
\hline Porong & 1,693 & $\begin{array}{c}934 \\
(7.62 \%)\end{array}$ & $\begin{array}{c}29 \\
(0.24 \%)\end{array}$ & $\begin{array}{c}439 \\
(3.58 \%)\end{array}$ & $\begin{array}{c}291 \\
(2.37 \%)\end{array}$ & $\begin{array}{c}1,693 \\
(13.81 \%)\end{array}$ \\
\hline Jabon & 1,273 & $\begin{array}{c}405 \\
(3.66 \%)\end{array}$ & $\begin{array}{c}6 \\
(0.05 \%)\end{array}$ & $\begin{array}{c}385 \\
(3.48 \%)\end{array}$ & $\begin{array}{c}477 \\
(4.31 \%)\end{array}$ & $\begin{array}{c}1,273 \\
(11.49 \%)\end{array}$ \\
\hline Tanggulangin & 2,325 & $\begin{array}{c}924 \\
(5.57 \%)\end{array}$ & $\begin{array}{c}19 \\
(0.11 \%)\end{array}$ & $\begin{array}{c}659 \\
(3.97 \%)\end{array}$ & $\begin{array}{c}723 \\
(4.36 \%)\end{array}$ & $\begin{array}{c}2,325 \\
(14.01 \%)\end{array}$ \\
\hline Candi & 5,001 & $\begin{array}{c}2,344 \\
(8.21 \%)\end{array}$ & $\begin{array}{c}32 \\
(0.11 \%)\end{array}$ & $\begin{array}{c}1,472 \\
(5.16 \%)\end{array}$ & $\begin{array}{c}1,153 \\
(4.04 \%)\end{array}$ & $\begin{array}{c}5,001 \\
(17.52 \%)\end{array}$ \\
\hline Sidoarjo & 9,678 & $\begin{array}{c}5,375 \\
(15.54 \%)\end{array}$ & $\begin{array}{c}73 \\
(0.21 \%)\end{array}$ & $\begin{array}{c}2,390 \\
(6.91 \%)\end{array}$ & $\begin{array}{c}1,840 \\
(5.32 \%)\end{array}$ & $\begin{array}{c}9,678 \\
(27.98 \%)\end{array}$ \\
\hline Tulangan & 3,924 & $\begin{array}{c}1,893 \\
(10.14 \%)\end{array}$ & $\begin{array}{c}32 \\
(0.17 \%)\end{array}$ & $\begin{array}{c}961 \\
(5.15 \%)\end{array}$ & $\begin{array}{c}1,038 \\
(5.56 \%)\end{array}$ & $\begin{array}{c}3,924 \\
(21.03 \%)\end{array}$ \\
\hline Wonoayu & 2,731 & $\begin{array}{c}1,042 \\
(6.02 \%)\end{array}$ & $\begin{array}{c}16 \\
(0.09 \%)\end{array}$ & $\begin{array}{c}793 \\
(4.58 \%)\end{array}$ & $\begin{array}{c}880 \\
(5.08 \%)\end{array}$ & $\begin{array}{c}2,731 \\
(15.78 \%)\end{array}$ \\
\hline Krian & 4,867 & $\begin{array}{c}2,237 \\
(9.32 \%)\end{array}$ & $\begin{array}{c}25 \\
(0.10 \%)\end{array}$ & $\begin{array}{c}1,150 \\
(4.79 \%)\end{array}$ & $\begin{array}{c}1,455 \\
(6.06 \%)\end{array}$ & $\begin{array}{c}4,867 \\
(20.27 \%)\end{array}$ \\
\hline Balongbendo & 2,039 & $\begin{array}{c}745 \\
(5.37 \%)\end{array}$ & $\begin{array}{c}13 \\
(0.09 \%)\end{array}$ & $\begin{array}{c}660 \\
(4.76 \%)\end{array}$ & $\begin{array}{c}621 \\
(4.48 \%)\end{array}$ & $\begin{array}{c}2,039 \\
(14.69 \%)\end{array}$ \\
\hline Taman & 1,071 & $\begin{array}{c}6,520 \\
(17.11 \%)\end{array}$ & $\begin{array}{c}22 \\
(0.06 \%)\end{array}$ & $\begin{array}{c}2,741 \\
(7.19 \%)\end{array}$ & $\begin{array}{c}1,688 \\
(4.43 \%)\end{array}$ & $\begin{array}{c}1071 \\
(28.80 \%)\end{array}$ \\
\hline Sukodono & 4,695 & $\begin{array}{c}1,917 \\
(7.43 \%)\end{array}$ & $\begin{array}{c}78 \\
(0.30 \%)\end{array}$ & $\begin{array}{c}1,543 \\
(5.98 \%)\end{array}$ & $\begin{array}{c}1,157 \\
(4.49 \%)\end{array}$ & $\begin{array}{c}4,695 \\
(18.20 \%)\end{array}$ \\
\hline Buduran & 3,124 & $\begin{array}{c}1,262 \\
(6.99 \%)\end{array}$ & $\begin{array}{c}37 \\
(0.21 \%)\end{array}$ & $\begin{array}{c}956 \\
(5.30 \%)\end{array}$ & $\begin{array}{c}869 \\
(4.82 \%)\end{array}$ & $\begin{array}{c}3,124 \\
(17.31 \%)\end{array}$ \\
\hline Gedangan & 5,556 & $\begin{array}{c}2,406 \\
(10.55 \%)\end{array}$ & $\begin{array}{c}17 \\
(0.07 \%)\end{array}$ & $\begin{array}{c}1,567 \\
(6.87 \%)\end{array}$ & $\begin{array}{c}1,566 \\
(6.87 \%)\end{array}$ & $\begin{array}{c}5,556 \\
(24.36 \%)\end{array}$ \\
\hline Sedati & 3,939 & $\begin{array}{c}2012 \\
(12.26 \%)\end{array}$ & $\begin{array}{c}29 \\
(0.18 \%)\end{array}$ & $\begin{array}{c}807 \\
(4.92 \%)\end{array}$ & $\begin{array}{c}1,091 \\
(6.65 \%)\end{array}$ & $\begin{array}{c}3,939 \\
(24.01 \%)\end{array}$ \\
\hline Waru & 13,882 & $\begin{array}{c}9,433 \\
(23.02 \%) \\
\end{array}$ & $\begin{array}{c}85 \\
(0.21 \%) \\
\end{array}$ & $\begin{array}{c}2,410 \\
(5.88 \%) \\
\end{array}$ & $\begin{array}{c}1954 \\
(4.77 \%) \\
\end{array}$ & $\begin{array}{c}13,882 \\
(33.88 \%) \\
\end{array}$ \\
\hline Total & 386,049 & $\begin{array}{c}42,491 \\
(11.01 \%)\end{array}$ & $\begin{array}{c}587 \\
(0.15 \%) \\
\end{array}$ & $\begin{array}{c}21,321 \\
(5.52 \%) \\
\end{array}$ & $\begin{array}{c}19,572 \\
(5.07 \%) \\
\end{array}$ & $\begin{array}{c}83,971 \\
(21.75 \%) \\
\end{array}$ \\
\hline
\end{tabular}

Source: End of Year Report Sub-Section KB-KK in DP3AKB Sidoarjo in 2018

The proportion value based on the most widely used contraceptive method and its region, IUD, has the highest proportion value in Waru, which is $23.02 \%$. However, the least use of the long-term contraceptive method, vasectomy method was in Sukodono. This result showed that most couples of childbearing age in choosing contraceptives in the form of the long-term contraceptive method in the
Sidoarjo was more interested in the IUD, while the least preferrable is vasectomy method by men of childbearing age.

The IUD (Intrauterine Device) method is the least preferred by the couples of childbearing age in Tarik with a contraceptive proportion value of $2.37 \%$, and the most preferred one in Sukodono with proportion value by $0.30 \%$ is vasectomy method. Most of 
the tubectomy method users belong to Taman, with the proportion of $7.19 \%$, while the least is in the Jabon by $3.48 \%$. The most users of implant method is in Prambon, with the proportion of $7.49 \%$, while the lowest users belong to Porong with a proportion of $2.37 \%$.

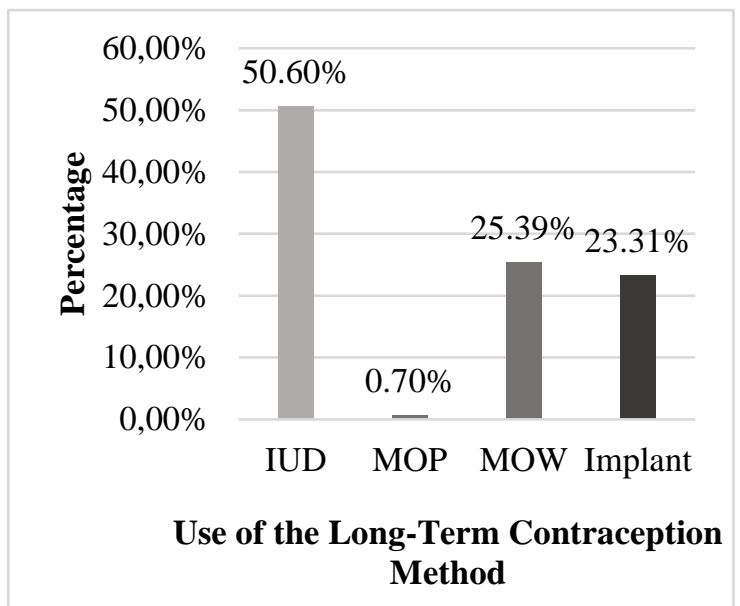

Figure 1. Distribution of the Long-Term Contraception Method Users in Sidoarjo

Figure 1 shows the distribution for active couples of childbearing age in Sidoarjo who use long-term contraceptive method, chose IUD method more wby $50.60 \%$. On the contrary, the least method preferred by couples of childbearing age was vasectomy with distribution percentage by $0.70 \%$. The longterm contraceptive method namely vasectomy was pretty preferred by couples of childbearing age in Sidoarjo with percentage on the second rank following IUD by $25.39 \%$, and in the third rank was implants method by $23.32 \%$. This showed that the distribution of long-term contraceptive method was more preferred by women compared to men during childbearing age in Sidoarjo.

\section{Testing the K-Means Cluster Assumptions}

Testing this assumption is done for requirements before further testing. The fulfillment of the conditions carried out in this analysis is a ratio scale, and variable data used that have the same unit, no correlation between variables (multicollinearity) using Bartletts's of sphericity test, and Kaiser Meyer Olkin (KMO) test to determine the data used can be analyzed cluster or representative sample.

The use of variables in this study is the level of contraceptive prevalence in each sub- district in Sidoarjo that uses long-term contraception, so that the data has a ratio scale, and the unit size studied is the same. Multicollinearity testing was tested through the Bartlett's of Sphericity Test, and representative sample testing was tested using the Kaiser Meyer Olkin Test. The results of both tests have values, as in table 2.

Table 2. The Kaiser Meyer Olkin and Bartlett's of Sphericity Test

\begin{tabular}{cccc}
\hline \multirow{2}{*}{ KMO } & \multicolumn{3}{c}{ Bartlett's of Sphericity } \\
\cline { 2 - 4 } & $\begin{array}{c}\text { Approx. Chi- } \\
\text { Square }\end{array}$ & df & p-value \\
\hline 0.549 & 11.390 & 6 & 0.077 \\
\hline
\end{tabular}

Hypothesis:

$\mathrm{H} 0=$ There is no correlation between the variables.

$\mathrm{H} 1=$ There is a correlation between the variables.

Table 2 shows the significant value in the Bartlett's of Sphericity test that is sig $=0.077$ $(\operatorname{sig}>\alpha=0.05)$, then the conclusion that can be drawn is $\mathrm{HO}$ is accepted, which means there is no correlation between variables so that the requirements have been met for not the occurrence of multicollinearity.

Testing the assumptions that have been carried out for the fulfillment of representative samples can be seen in table 2, for the value of Kaiser Meyer Olkin (KMO) obtained is 0.549, which means that the value has met the representative sample because the value of the Kaiser Meyer Olkin test results is between 0.5 $\leq \mathrm{KMO} \leq 1$

The results of assumptions testing on the variable prevalence level of users of the longterm contraceptive method that all assumptions from the data scale, not the occurrence of multicollinearity, and representative samples are fulfilled then, these variables can be tested for further analysis namely K-Means analysis.

\section{K-Means Cluster Analysis.}

After testing the assumptions, the next step is testing the K-Means cluster analysis of the sub-districts in the Sidoarjo based on the value of the contraceptive proportion using the longterm method in each sub-district having the results in Tables 3 and 4 below. 
Table 3. Final Cluster Centers

\begin{tabular}{lrrr}
\hline \multirow{2}{*}{ Variable } & \multicolumn{3}{c}{ Cluster } \\
\cline { 2 - 4 } & $\mathbf{1}$ & \multicolumn{1}{c}{$\mathbf{2}$} & \multicolumn{1}{c}{$\mathbf{3}$} \\
\hline IUD & -0.666339 & -0.07623 & 1.44112 \\
MOM & -0.69481 & 1.02474 & -0.14748 \\
MOW & -0.63985 & -0.08546 & 1.40790 \\
Implant & -0.11358 & 0.01135 & 0.21013 \\
\hline
\end{tabular}

Table 3 shows that there are 3 clusters or groups with negative values (-) which explain the type of contraceptive method variable is lower than the standard, while the positive value (+) describes the variable type of contraceptive method is located higher than the standard. Table 3 can explain that cluster 1 has regional members with below standard or average contraceptive proportions in the IUD (Intrauterine Device) method, vasectomy, tubectomy, and implants, so it can be said to be the low-level success is owned by Cluster 1 . Cluster 2 has members of the region with a proportion of contraception below the IUD (Intrauterine Device) and tubectomy methods.

Cluster 3 shows that there are regional members with sub-standard prevalence in the vasectomy method, and have regional members with contraceptive proportions above the standard for the IUD, tubectomy, and implant methods. Cluster 3 has three methods that assess the proportion of contraception above the average. It can be said that the success rate of a group or cluster 3 is high. The results of the grouping or clustering of sub-districts in Sidoarjo are explained in table 4.

Table 4 shows Cluster 1 or the category of regions with low success rates having eight subdistrict members, namely Tarik, Prambon, Jabon, Tanggulangin, Candi, Wonoayu, Krian, and Balongbendo. The cluster shows that the district has a proportion of users using the longterm contraceptive method below the average or standard in the Sidoarjo. Cluster 2 or a category of regions with moderate success in using the long-term contraceptive method has six members of the region including Krembung, Porong, Tulangan, Sukodono, Buduran, and Sedati Districts; it can be interpreted that the district has a higher proportion of the long-term contraceptive method users than the districts in Cluster 1, however still lower than the subdistricts in Cluster 3.
Table 4. Results of Sub-districts Grouping Based on Prevalence Level of the Long-Term Contraceptive Method in Sidoarjo

\begin{tabular}{cll}
\hline Cluster & Category & \multicolumn{1}{c}{ sub-district } \\
\hline 1 & Low & Tarik \\
1 & Low & Prambon \\
1 & Low & Jabon \\
1 & Low & Tanggulangin \\
1 & Low & Candi \\
1 & Low & Wonoayu \\
1 & Low & Krian \\
1 & Low & Balongbendo \\
2 & Medium & Krembung \\
2 & Medium & Porong \\
2 & Medium & Tulangan \\
2 & Medium & Sukodono \\
2 & Medium & Buduran \\
2 & Medium & Sedati \\
3 & High & Sidoarjo \\
3 & High & Taman \\
3 & High & Gedangan \\
3 & High & Waru \\
\hline
\end{tabular}

\section{DISCUSSION}

Family Planning Program includes ensuring the availability of contraceptives. Long-term contraceptive method is a type of pregnancy spacing media or prevention of unwanted pregnancies that is effective in economic terms. Efforts to increase the number of long-term contraceptive method users aim to increase the Contraceptive Prevalence Rate (Ihsani, Wuryaningsih, and Sukarno, 2019).

The formation of groups occurs because it has the same characteristics in the number of the long-term contraceptive method users in each district, such as in Cluster 1 consisting of Tarik, Prambon, Jabon, Tanggulangin, Candi, Wonoayu, Krian, and Balongbendo subdistricts. Cluster 1 was formed because it has a percentage of the proportion of users in the type of contraceptive IUD, vasectomy, tubectomy, and implants below the average the long-term contraceptive method users, which means it still seldom chooses the the long-term contraceptive method in the Cluster 1 region, so that in Cluster 1 is categorized as quite successfully in long-term use of contraceptive. Cluster 2 consists of Krembung, Porong, 
Tulangan, Sukodono, Buduran, and Sedati subdistricts.

Characteristics of cluster 2 are the percentage of contraceptive users using the vasectomy and implants methods above the average use of the long-term contraceptive method in Sidoarjo. This result shows that couples of childbearing age prefer both types of contraceptives and can be said in Cluster 2 to have good long-term success in contraception. Cluster 3 consisting of Sidoarjo, Taman, Gedangan, and Waru Districts is a member that has a high percentage of users from the average of long-term contraceptive method users in Sidoarjo are IUD, tubectomy, and implants methods. This can show that couples of childbearing age in the Cluster 3 region chose all three methods. The use of this type of contraception is almost comprehensive in each long-term method, and it can be said that the regions in Cluster 3 show an excellent success.

Cluster 1 shows a low success rate in the use of the long-term contraceptive method. This condition occurred in Balongbendo, where many couples of childbearing age were not present at the family planning program socialization that had been scheduled due to community stigma about family planning programs that were still contrary to tradition or religion. The absence of participants in the socialization shows that the implementation of the family planning program has not yet been fulfilled (Najihah, 2017). In line with research Kaniki (2019), the main factor influencing decision-making in contraception is religious fraud $(67.4 \%)$. The existence of long-term contraceptive methods and the percentage to choose this method is also enormous (50\%) (Septalia and Puspitasari, 2017).

One example of a sub-district in Cluster 2, Sukodono, shows the role of Family Planning Field Officers has provided regular scheduled guidance and outreach. However, there are obstacles such as, the task load is too high due to the lack of officers and the limited facilities and infrastructure to support the sustainability of activities (Setyowati, Arsiyah, and Balahmar, 2016). The lack of staff and limited facilities and infrastructure indirectly prevent the community from obtaining information; this is in line with research Aina (2018) that the determining factor in obtaining information is how easy the informant can access the information.
Unlike the case in Cluster 3, one example in Waru, in the implementation of the family planning program the Family Planning Field Officers is responsive and ready to serve and socialize to the community and vice versa the community is also very enthusiastic in participating so that in this case can support the implementation of the family planning program itself. However, another obstacle is that the community's knowledge is still lacking in receiving information (Bachtiyar and Wibawani, 2017). Lack of knowledge from the community has the same study Sumartini, and Indriani (2017) explained that knowledge did not affect the selection of contraceptives at the the long-term contraceptive method. On contrary with research conducted by Indahwati, Wati, and Wulandari (2017) which stated that women of childbearing age's knowledge is influential when choosing the contraceptive method to be used.

Another aspect that influences the determination of long-term contraceptive is the the residential area, whether it is rural or urban areas (Triyanto and Indriani, 2018). Based on Central Bureau of Statistics Sidoarjo data 2020, Sidoarjo is $0 \mathrm{~km}$ away from the district center, while Buduran is $5 \mathrm{~km}$, Waru is $19 \mathrm{~km}$, and Taman is $20 \mathrm{~km}$ from the district center. Cluster 2 members consisting of the Krembung is 29 $\mathrm{km}$ from the district center, Porong and Tulangan are $14 \mathrm{~km}$, Sukodono is $12 \mathrm{~km}$, Buduran is $5 \mathrm{~km}$, and Sedati is $14 \mathrm{~km}$ from the district center. This condition shows that the distance in Cluster 2 to the capital city has a moderate distance.

Members of Cluster 1 include Tarik, the farthest from the center of the district which is $33 \mathrm{~km}$, Prambon is $27 \mathrm{~km}$, Jabon is $21 \mathrm{~km}$, Tanggulangin is $9 \mathrm{~km}$, Candi is $6 \mathrm{~km}$, Wonoayu is $19 \mathrm{~km}$, Krian is $22 \mathrm{~km}$, and Balongbendo is $26 \mathrm{~km}$ from the district center. This condition shows that Cluster 3 members are urban areas or close to urban areas because they have an average distance to the district center that is quite close. Vice versa, cluster 1 have an average distance away from urban areas, in line with research by Triyanto and Indriani (2018) that the choice of long-term contraceptive method is influenced by residential area of the fertile age couple.

In line with the study Cahyati, Herawatie and Wuryanto (2017), grouping or clustering can be done using a ratio of contraceptive users 
having 3 clusters with different success rates. The number of couples of childbearing age that choose the long-term contraceptive method can also be influenced by institutions providing family planning programs. From the results of evaluating the implementation of population growth control policies in Sidoarjo Regency, it is still lacking in communicating education and service information, and a lack of human resources in the field (Diro, Arsiyah, and Mahbub, 2014).

The area also influences the choice of longterm contraceptive methods, kThe arena for organizing family planning services is the responsibility of district and city offices in the region. It is expected that by each region, the region can process its problems according to its resources (Indonesian Ministry of Health, 2014).

\section{CONCLUSIONS AND SUGGESTIONS.}

\section{Conclusion}

The results of grouping using K-Means cluster analysis show three clusters formed based on the proportion of the Long-Term Contraception Method users in the Sidoarjo Regency. Cluster 1 is a sub-district with a low success rate category using the Long-Term Contraception Method, which has eight members, namely the Districts of Tarik, Prambon, Jabon, Tanggulangin, Candi, Wonoayu, Krian, and Balongbendo. Cluster 2 is a sub-district with moderate success in using the Long-Term Contraception Method, which has six members consisting of Krembung, Porong, Tulangan, Sukodono, Buduran, and Sedati. Cluster 3 is a sub-district area with a high success rate category in the use of the LongTerm Contraception Method consisting of 4 sub-districts: Sidoarjo District, Parks, Gedangan, and Waru.

A large proportion of the long-term contraceptive method users showed a large number in the region. This condition is influenced by society attitudes that rejects or accepts family planning programs and family planning service officers, such as socialization about family planning. The residential area (rural and urban) is also a factor influencing couples of childbearing age in choosing the contraceptive method.

\section{Suggestion}

Following the study results, advice can be given in order to expand access to information to couples who will marry or after marriage about the choice of contraceptive methods. One of the activities that can be applied is interesting communication, information, and education strategy to do family planning counseling and midwives in the sub-districts. Sub-districts in the clusters with a low success rate must optimize communication, information, and education for the long-term contraceptive method and the fulfillment of health services, health workers, and medical personnel to reach or access more easily.

\section{REFERENCES}

Aina, N., 2018. Analisis Faktor yang Memengaruhi Kebutuhan Ber-KB dengan Pendekatan Social Cognitive Theory. Jurnal Biometrika dan Kependudukan, 7(1), pp.1-10.

Azizah, E.W., Sudarti and Kusuma, H., 2018. Pengaruh Pendidikan, Pendapatan Perkapita dan Jumlah Penduduk terhadap Kemiskinan di Provinsi Jawa Timur. Jurnal Ilmu Ekonomi, 2(1), pp.167-180.

Bachtiyar, N.A. and Wibawani, S., 2017. Implementasi Program Kampung Keluarga Berencana di Dusun Ambeng-Ambeng Desa Ngingas Kecamatan Waru Kabupaten Sidoarjo. Jurnal Dinamika Governance, 7(1), pp.13-26.

Central Bureau of Statistics, 2012. Penduduk Indonesia Menurut Provinsi 1971, 1980, 1990, 1995, 2000 dan 2010. [online] Available at: <https://www.bps.go.id/statictable/2009/0 2/20/1267/penduduk-indonesia-menurutprovinsi-1971-1980-1990-1995-2000-dan2010.html>.

Central Bureau of Statistics, 2017. Laju Pertumbuhan Penduduk menurut Provinsi. [online] Available at: <https://www.bps.go.id/statictable/2009/0 2/20/1268/laju-pertumbuhan-pendudukmenurut-provinsi.html>.

Cahyati, E.D., Herawatie, D. and Wuryanto, E., 2017. Implementasi K-Means Clustering untuk Pemetaan Desa dan Kelurahan di Kabupaten Bangkalan Berdasarkan 
Contraceptive Prevalence Rate dan Tingkat Pendidikan. Seminar Nasional Matematika dan Aplikasinya, pp.341-348.

Diro, A., Arsiyah and Mahbub, Z., 2014. Implementasi Kebijakan Pengendalian Pertumbuhan Penduduk di Kabupaten Sidoarjo. Jurnal Kebijakan dan Manajemen Publik (JKMP), 2(1), pp.1528.

Idris, H., 2019. Factors Affecting the Use of Contraceptive in Indonesia: Analysis from the National Socioeconomic Survey (Susenas). KEMAS: Jurnal Kesehatan Masyarakat, 15(1), pp.117-123.

Ihsani, T., Wuryaningsih, C.E. and Sukarno, 2019. Peran Pengambilan Keputusan Penggunaan MKJP di Indonesia (Analisis Lanjut Data SRPJMN Tahun 2017). Jurnal Keluarga Berencana, 4(2), pp.11-19.

Indahwati, L., Wati, L.R. and Wulandari, D.T., 2017. Usia dan Pengalaman KB Berhubungan dengan Pemilihan Metode Kontrasepsi. Journal of Issues in Midwifery, 1(2549-6581), pp.1-18.

Indonesian Ministry of Health, 2013. Kesehatan Reproduksi dan Keluarga Berencana. Buletin Jendela Data dan Informasi Kesehatan, 2(2).

Indonesian Ministry of Health, 2014. Pedoman Manajemen Pelayanan Keluarga Berencana. Revisi ed. Jakarta: Indonesian Ministry of Health.

Kaniki, F., 2019. Factors Influencing the Use of Modern Contraceptive Methods among Rural Women of Child Bearing Age in the Democratic Republic of the Congo. Journal of Family Medicine and Primary Care, 8(8), pp.2582-2586.

Khoirunnisa, S. and Dzikkrullah, A.A., 2020. Pengelompokan Kecamatan Berdasarkan Alat Kontrasepsi KB Aktif dengan Metode K-Means di DIY. Seminar Nasional Matematika dan Pendidikan Matematika (Sendika), 6(1), pp.104-109.

Kuntoro, 2011. Metode Statistik. Revisi ed. Surabaya: Melati.

Najihah, D., 2017. Resistensi Masyarakat Terhadap Program Keluarga Berencana (KB) (Studi di Desa Penambangan Kecamatan Balongbendo Sidoarjo). Thesis. Universitas Muhammadiyah Malang.

National Board of Population and Family Planning and Central Bureau of Statistics, 2019. Survei Kinerja dan Akuntabilitas

\section{Program KKBPK (SKAP) Keluarga.} Jakarta.

National Board of Population and Family Planning, Central Bureau of Statistics, Indonesian Ministry of Health and USAID, 2018. Survei Demografi Kesehatan Indonesia 2017. Jakarta.

Nugroho, D.Y. and Wibowo, A., 2019. Analisis Cluster K-Means Kabupaten/Kota di Jawa Timur Berdasarkan Level Epidemik HIV. Jurnal Biometrika dan Kependudukan, 8(2), pp.109-119.

Öztürk İnal, Z., İnal, H.A., Küçükkendirci, H., Sargin Oruç, A. and Günenç, O., 2017. The Level of using Family Planning Methods and Factors that Influence the Preference of Methods in The Konya-Meram Area. Journal of the Turkish German Gynecological Association, 18(2), pp.7276.

Parsian, M., 2015. Data Algorithms: Recipes for Scaling Up with Hadoop and Spark. USA: O'Reilly Media.

Peterson, E.W.F., 2017. The Role of Population in Economic Growth. SAGE Open, 7(4), pp.1-15.

Restiani, I.D., 2016. Pengelompokkan Kabupaten/Kota di Provinsi Jawa Timur Berdasarkan Peserta KB. Thesis. Institut Teknologi Sepuluh November.

Septalia, R. and Puspitasari, N., 2017. Faktor yang Memengaruhi Pemilihan Metode Kontrasepsi. Jurnal Biometrika dan Kependudukan, 5(2), pp.91-98.

Setyowati, E., Arsiyah and Balahmar, A.R., 2016. Peran Petugas Lapangan Keluarga Berencana dan Pembantu Pembina Keluarga Berencana Desa dalam Mensosialisasikan Alat Kontrasepsi. Jurnal Kebijakan dan Manajemen Publik (JKMP), 4(2), pp.169-182.

Silvi, R., 2018. Analisis Cluster dengan Data Outlier Menggunakan Centroid Linkage dan KMeans Clustering untuk Pengelompokkan Indikator HIV/AIDS di Indonesia. Jurnal Matematika "MANTIK", 4(1), pp.22-31.

Sumartini and Indriani, D., 2017. Pengaruh Keinginan Pasangan Usia Subur (Pus) dalam Penggunaan Metode Kontrasepsi Jangka Panjang. Jurnal Biometrika dan Kependudukan, 5(1), pp.27-34.

Triyanto, L. and Indriani, D., 2018. Faktor yang Memengaruhi Penggunaan Jenis Metode Kontrasepsi Jangka Panjang (MKJP) pada 
170 Jurnal Biometrika dan Kependudukan, Volume 9, Issue 2 December 2020: 161-170

Wanita Menikah Usia Subur di Provinsi Jawa Timur. The Indonesian Journal of Public Health, 13(2), pp.244-255.

Wati, D.A.M., Puspitasari, D. and Purwaningsih, E., 2019. Metode Clustering pada Model Algoritma K-Means untuk Pemilihan Alat Kontrasepsi. Informatics for Educators and Professionals, 3(2), pp.129-138.

Yulianti, I.F., 2018. Segmentasi Provinsi Berdasarkan Indikator Kinerja Utama Program KKBPK Menggunakan K-Means Cluster. In: Prosiding Seminar Nasional Statistika, Departemen Statistika, FMIPA Universitas Padjadjaran, 7(1). 